\title{
A SURVEY OF AWARENESS, TRAINING AND COMPLIANCE REGARDING UNIVERSAL PRECAUTIONS AMONG HOUSE OFFICERS IN A PERIPHERAL TEACHING HOSPITAL IN HIV ENDEMIC AREA.
}

1. MBBS, FCPS

Senior Registrar Surgery

Nawaz Sharif Medical College.

2. MBBS, FCPS

Associate Professor Surgery

Nawaz Sharif Medical College.

3. MBBS

House Officer Surgery

Nawaz Sharif Medical College.

4. MBBS

Post-Graduate Trainee Surgery Nawaz Sharif Medical College.

5. MBBS, FCPS

Professor Surgery

Nawaz Sharif Medical College.

Correspondence Address:

Dr. Saleeem Raza Shah

Department of Surgery

Nawaz Sharif Medical College.

drsaleemrazashah1970@gmail.com

Article received on:

18/01/2020

Accepted for publication:

03/04/2020

\begin{abstract}
Saleeem Raza Shah', Sajid Aziz², Ovais Ahmed Cheema ${ }^{3}$, Salman Farooq Dar ${ }^{4}$, Muhammad Ateeq ${ }^{5}$
\end{abstract}
ABSTRACT... The purpose of this study is to access the level of knowledge, training and compliance of these house officers to universal precautions to HIV transmission. Study Design: Cross Sectional study. Setting: Aziz Bhatti Shaheed Teaching Hospital Gujrat. Period: July-September 2019. Material \& Methods: Self reported questionnaires were provided to 80 house officers and results were analyzed in SPSS 20. Results: knowledge attitude and compliance of house officers towards universal precautions was not up to date. This could be due to the fact that $78.79 \%$ of our participants have not received any form of training regarding universal precautions. Conclusion: It is urgently needed that training sessions for newly recruited doctors are arranged on regular basis to prepare them protect themselves against communicable diseases. Also strategies should be devised to implement strict compliance to universal precautions.

Key words: $\quad$ Acquired Immunodeficiency Syndrome, AIDS, Attitude, Compliance, Endemic Area, Human Immunodeficiency Virus, HIV, House Officers, Knowledge, Universal Precautions.

Article Citation: Shah SR, Aziz S, Cheema OA, Dar SF, Ateeq M. A survey of awareness, Training and compliance regarding universal precautions among house officers in a peripheral teaching hospital in HIV endemic area. Professional Med J 2020; 27(9):1936-1941. DOI: 10.29309/TPMJ/2020.27.09.4492

\section{INTRODUCTION}

Acquired immunodeficiency syndrome (AIDS) is a disease caused by human immunodeficiency virus (HIV) which is an RNA virus. The disease is characterized by decline in individuals immunity resulting in recurrent infections with common organism, in severe form, as well infections with otherwise non-pathogenic organisms. It is transmitted via body fluids namely blood, milk, semen etc as well as from mother to child during birth. AIDS is considered as sexually transmitted disease but other modes of transmission have also become common. ${ }^{1}$ There is no cure, but there are certain drugs that slow the disease progression, so prevention is the best strategy. ${ }^{2}$

The term "universal precautions was coined in 1987 by CDC which recommended that precautions should be constantly used regardless of patient's infection status, also known as "universal blood and body fluid precautions". ${ }^{3}$ It was later modified into "standard precautions" on 1996 which includes; barrier method (gown, gloves, goggles etc); careful use of devices, clothing and equipment; environmental control (surface processing, waste management); proper discarding of needles and sharp objects; and patient's segregations according to requirements. ${ }^{4}$

According to World Health Organization estimate, about 1000 healthcare professionals were infected with HIV due to sharp injuries in year 2002. ${ }^{5}$ This shows that healthcare professionals by inherent nature of their job are at increased risk of transmission of HIV. ${ }^{6}$ During 19852013, 58 confirmed and 150 possible cases of occupationally acquired HIV infection among health care workers were reported to CDC. ${ }^{7}$

There is a greater risk of HIV transmission in developing countries due to inadequate occupational health program in healthcare system. ${ }^{8}$ There are a number of studies that identify 
the lack in awareness and compliance among healthcare professionals regarding universal precautions. ${ }^{7}$ In some studies identify lack of adequate equipment was considered as the most common factor obstructing the adherence to universal precautions ${ }^{10}$, while others attributed it to increased work load in healthcare facilities. ${ }^{11}$

National AIDS control program Pakistan has estimated number of HIV infected individuals to be around 0.165 million. Out of which 24,331 know their HIV status and 17,149 are on retroviral therapy. Recent epidemic of AIDS in Gujrat (Pakistan) has been documented in various studies. ${ }^{12}$ There are more than 2000 registered AIDS patients in different AIDS treatment centers in district Gujrat, Pakistan.

A study by Jawaid et al recognized the lack of knowledge attitude and compliance regarding standard precautions among doctors at a tertiary care hospital in Pakistan. Non-availability of equipment $(70 \%)$ was recognized as the most common reason for non-compliance. ${ }^{13}$

A lot of new doctors are being recruited at Aziz Bhatti Shaheed Teaching hospital Gujrat as house officer, due to its upgrading to a teaching hospital, which are exposed to endemic population of AIDS, hence putting them at high risk. These newly recruited house officers have graduated from local as well as foreign medical colleges creating much diversity. The purpose of this study is to access the level of knowledge, training and compliance of these house officers to universal precautions to HIV transmission. It will then help us identify the deficiencies in training and formulate strategies for better education of healthcare staff.

\section{MATERIAL \& METHODS}

Cross sectional study was done at Aziz Bhatti Shaheed Teaching Hospital Gujrat during July-September 2019. All house officers were included in the study. All healthcare staff, other than house officers was excluded. Self-reporting questionnaire, taken from Measurement Instrument Database for the Social Science, was provided to 80 house officers. ${ }^{14}$ Implied consent was considered for voluntary return of questionnaires. Data was analyzed with SPSS 20 and tabulated results were generated for likert scale charts.

\section{RESULTS}

Out of 80 house officers reached, 66 responded, making response rate of $82.5 \%$. The results are tabulated below:

Expected frequencies are shown and chi square distribution was used. The critical value is less than chi square value and $p$-value is less than $0.05 \%$. So the null hypothesis $\mathrm{H}_{0}$; the role of ulcer grading has no significant role as a predictor level of amputation in diabetic foot ulcer patients was rejected.

\begin{tabular}{|l|c|}
\hline \multicolumn{2}{|c|}{ Gender } \\
\hline Male & Female \\
\hline Count & Count \\
\hline 21 & 45 \\
\hline & \\
\hline
\end{tabular}

\section{DISCUSSION}

This study attempted to identify the deficiencies in knowledge, attitude and compliance towards universal precautions among newly recruited doctors at Aziz Bhatti Shaheed Teaching Hospital Gujrat.

Knowledge of our house officers regarding HIV transmission and universal precautions is not up to date. For example, despite it being a well known fact that district Gujrat has a relatively high prevalence of HIV, as advertised by local and national media only $46.97 \%$ participants answered the question with surety. ${ }^{11}$ For the question that asymptomatic AIDS patients can transmit the disease, $63.64 \%$ participants gave a definite true. On the other hand, nearly everyone thinks that AIDS does not spread via skin touch. But knowledge regarding toilet seats as a source of transmission is poor where only $62.12 \%$ or participants answered with surety as compared to $96.8 \%$ by Aisien $\mathrm{AO}$ et al. ${ }^{15}$ 


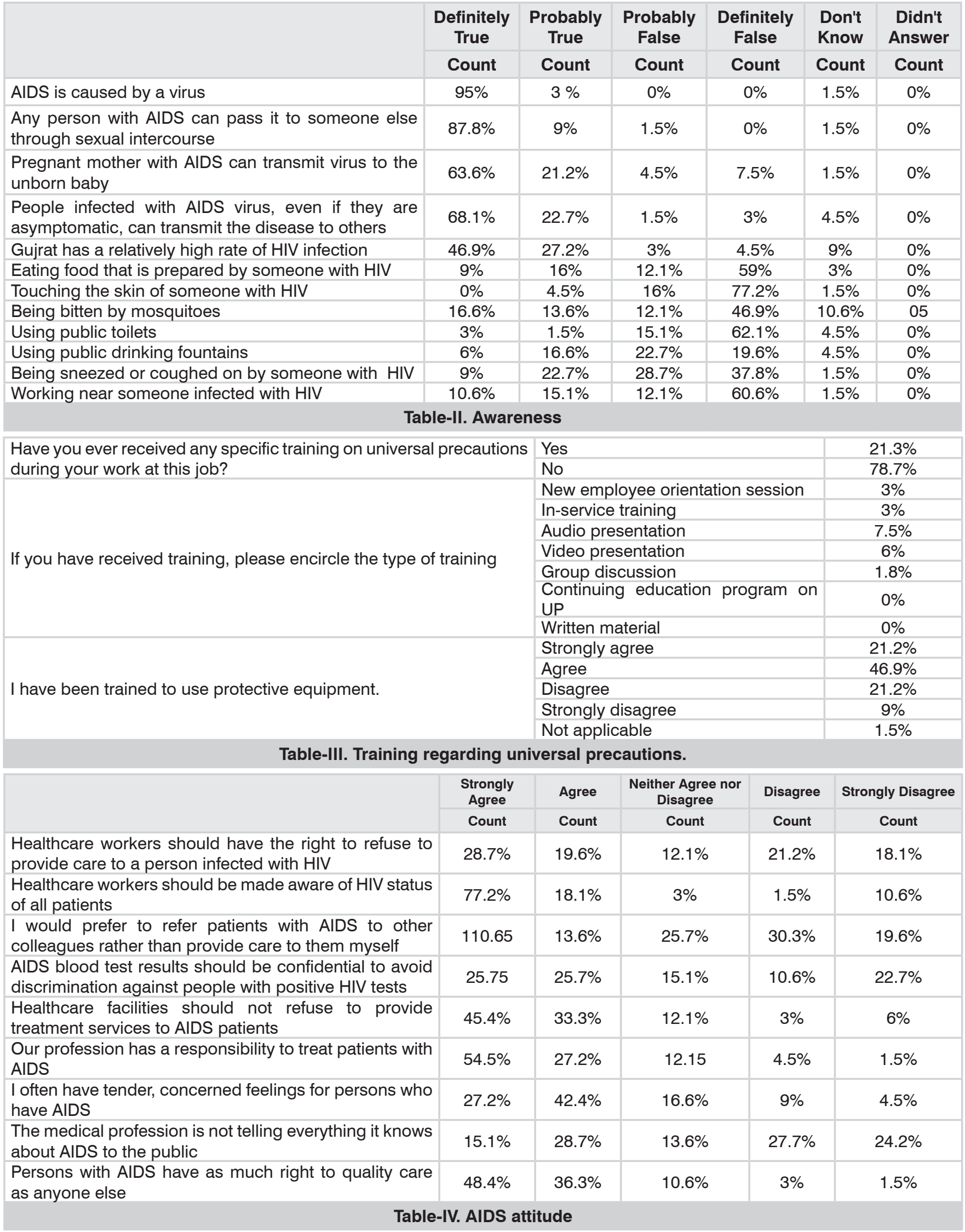




\begin{tabular}{|c|c|c|c|c|c|c|}
\hline & Always & Often & Sometimes & Rarely & Never & $\begin{array}{l}\text { Not } \\
\text { Applicable }\end{array}$ \\
\hline & Count & Count & Count & Count & Count & Count \\
\hline Treat all patients as if they are infected with HIV & $37.8 \%$ & $19.6 \%$ & $6 \%$ & $13.6 \%$ & $19.6 \%$ & $1.5 \%$ \\
\hline Follow UP in all patients regardless of their diagnosis & $30 \%$ & $21.2 \%$ & $34.8 \%$ & $7.5 \%$ & $4.5 \%$ & $0 \%$ \\
\hline $\begin{array}{l}\text { Wear a disposable outer garment that is resistent to blood } \\
\text { and body fluids whenever there is a chance of soiling my } \\
\text { clothes at work }\end{array}$ & $30.3 \%$ & $16.6 \%$ & $19.6 \%$ & $10.6 \%$ & $21.2 \%$ & $0 \%$ \\
\hline $\begin{array}{l}\text { Wear disposable gloves whenever there is a possibility of } \\
\text { exposure to blood or other body fluids }\end{array}$ & $56 \%$ & $25.7 \%$ & $7.5 \%$ & $1.5 \%$ & $4.5 \%$ & $3 \%$ \\
\hline $\begin{array}{l}\text { Dispose of all potentially contaminated material into red/or } \\
\text { labelled bag for disposal of biomedical waste }\end{array}$ & $30 \%$ & $37.8 \%$ & $9 \%$ & $6 \%$ & $10.6 \%$ & $4.5 \%$ \\
\hline $\begin{array}{l}\text { Promptly wipe up all potentailly contaminated spills with } \\
\text { disinfectant }\end{array}$ & $12.1 \%$ & $18.1 \%$ & $13.6 \%$ & $16.6 \%$ & $33.3 \%$ & $4.5 \%$ \\
\hline $\begin{array}{l}\text { Eat or drink while working in area where there is possibility } \\
\text { of becoming contaminated with blood of body fluids }\end{array}$ & $42.4 \%$ & $24.2 \%$ & $15.1 \%$ & $6 \%$ & $1.5 \%$ & $9 \%$ \\
\hline $\begin{array}{l}\text { Take special caution when using scalpels or other sharp } \\
\text { objects }\end{array}$ & $56 \%$ & $22.7 \%$ & $7.5 \%$ & $4.5 \%$ & $4.5 \%$ & $3 \%$ \\
\hline Recap needles that have been contaminated with blood & $43.9 \%$ & $25.7 \%$ & $16.6 \%$ & $3 \%$ & $4.5 \%$ & $4.5 \%$ \\
\hline
\end{tabular}

Table-V. Compliance towards universal precautions.

Knowledge of our participants was a lower than a study done by Kermode M in Rural India where most of the participants correctly answered the question regarding pregnant mothers, being sneezed or coughed upon, eating with HIV patient. ${ }^{16}$ Again when compared with a study done by Vaz $\mathrm{K}$ et al, knowledge of our doctors was poor. These findings could possibly be due to the fact that doctors included in other studies were somewhat more experienced. ${ }^{17}$ The fact that experienced healthcare workers are more knowledgeable than junior ones was depicted by Ogonia D et al in 2015. ${ }^{18}$

The response regarding attitude towards AIDS and HIV positive patients is that the point where most of the participants agree, also with Aisien
$\mathrm{AO}$ et al, is that they should be made aware of the patients HIV status. ${ }^{15}$ Less of our participants would refer an AIDS patient to their colleagues when compared with Kemrode $\mathrm{M}$ et al. ${ }^{16}$ Nearly half of our participants (48.48\%) show solidarity on the fact that health care workers should have the right to refuse healthcare to a person infected with HIV but then at the same time they also agree that a person infected with AIDS has a much right to quality healthcare as anyone else $(84.85 \%)$ and the health care facility should not refuse treatment to HIV positive patients (78.79\%). This dilemma probably highlights their inside fears of being afflicted with HIV and was consistent with the study of Gershon RR et al from which the questionnaire was taken. ${ }^{19}$ This fear may arise from the deficiency in knowledge 
and training regarding transmission of HIV and safety measures against it.

Regarding compliance, only 56\% responded that they always wear disposable gloves for protection from contamination. This number was even lower for; face masks $43.94 \%$, splash resistant gowns $30.03 \%$ and eye shields $27.27 \%$. These are a lot poor results as compared to Kotwal A. ${ }^{20}$ To compare it, study by Sadoh showed that less than $2 / 3^{\text {rd }}$ of the participants stated that they always wore protective gear during surgeries and obstetrics care. ${ }^{21}$ Another study in Pakistan by Jawaid et al, showed even poorer results with use of apron $58.3 \%$, gloves $20.8 \% \%$, masks $2.5 \%$ and goggles $0.00 \% .{ }^{13}$ It has been demonstrated by Danchaivijitr $S$ that lack of understanding regarding the use of protective equipments can lead to higher rates of non-compliance which could be the cause in our participants as well. ${ }^{22}$ The perception of increased workload among healthcare professional can also be a cause of non-compliance to universal precautions to accommodate work pressure in limited time. ${ }^{23,24}$

This fear and lack of knowledge might be due to the fact that out of 66 doctors included in our research 52 (78.79\%) haven't received any form of training on universal precautions regarding AIDS and how it affects our working environment. As in 2016, llyasau et al have identified gaps in knowledge of doctor regarding precautions against communicable diseases despite regular training. They even suggest regular refresher courses on this topic. ${ }^{25}$

\section{LIMITATIONS}

Survey was mainly done on house officers of Aziz Bhatti Shaheed Teaching Hospital Gujrat. Nurses and paramedics were not included in the study due to language barrier as there was a possibility that most of them might not understand the nature of questions in English causing error in results.

\section{CONCLUSION}

It is urgently needed that training sessions for newly recruited doctors are arranged on regular basis to prepare them protect themselves against communicable diseases. Also strategies should be devised to implement strict compliance to universal precautions. In this domain, universal precautions can be made part of the curriculum for medical students and house officers.

Copyright $@ 03$ Apr, 2020.

\section{REFERENCES}

1. Bennet NJ, Gilroy SA. HIV infections and AIDS. Medscape 01 July 2019. Available at URL: https://emedicine. medscape.com/article/211316-overview\#a2.

2. Robert T. Schooley, John W. Mellors, No Cure Yet for HIV1, But Therapeutic Research Presses On, The Journal of Infectious Diseases, Volume 195, Issue 6, 15 March 2007, Pages 770-772, https://doi.org/10.1086/511830

3. McCarthy GM. Universal precautions J Can Dent Assoc 2000; 66:556-7.

4. Garner JS. Hospital infection control practices advisory committee. Guideline for isolation precautions in hospitals. Infect Hosp Epidemiol 1996; 17:53-80.

5. Pruss-Ustun A, Rapiti E, Hutin Y. Estimation of the global burden of disease attributable to contaminated sharps injuries among health-care workers. Am J Ind Med 2005; 48(6):482-90.

6. Khuri-Bulos NA, Toukan A, Mahafzah A, et al. Epidemiology of needle stick and sharp injuries at a university hospital in a developing country: A 3-year prospective study at the Jordan University Hospital, 1993 through 1995. Am J Infect Control 1997; 25(4):322-9.

7. Morbidity and mortality weekly report. 2015; 63(53):1245-1246. (c) 2015 Centers for Disease Control and Prevention (CDC).

8. Asogwa SE. A guide to occupational health practice in developing countries, 2 Edition, SNAAP Press Ltd., Enugu, Nigeria. 2000:10-25.

9. Earl C (2016) Ecuador health professionals perceived knowledge and beliefs about HIV and the use of standard precautions a cross-sectional descriptive research study. Int J Nurs Clin Pract 3: 169.

10. Adinma ED, Ezeama C, Adinma JIB, Asuzu MC. Knowledge and practice of universal precautions against Blood borne pathogens amongst house officers and nurses in tertiary health institutions in southeast Nigeria. Nigerian Journal of Clinical Practice December 2009 Vol. 12(4):398-402. 
11. Okechukwu EF, Motshedisi C. Knowledge and practice of standard precautions in public health facilities in Abuja, Nigeria. International Journal of Infection Control. 2012 Aug 9; 8(3).

12. Ansari JA, Salman M, Safdar RM, Ikram N, MAhmood T, Zaheer HA, Walke H, Asghar RJ. HIV/AIDS outbreak investigation in Jalalpur Jattan (JPJ), Gujrat, Pakistan. Journal of Epidemiology and Global Health (2013), Vol:3(4); 261- 268.

13. Jawaid $M$, lqbal $M$, Shahbaz $S$. Compliance with standard precautions: A long way ahead. Journal of Public Health 2009; 38:85-8.

14. Gershon, R. R. M., Vlahov, D., Felknor, S. A., Vesley, D., Johnson, P. C., Delclos, G. L., \& Murphy, L. R. (2012). Healthcare worker questionnaire. Measurement instrument database for the social science. Retrieved from www.midss.ie.

15. Aisien AO, Shobowale MO. Health care workers' knowledge on HIV and AIDS: Universal precautions and attitude towards PLWHA in Benin-City, Nigeria. Nigerian Journal of Clinical Practice. 2005; 8(2):74-82.

16. Kermode M, Holmes W, Langkham B, Thomas MS, Gifford S. HIV-related knowledge, attitudes \& risk perception amongst nurses, doctors \& other healthcare workers in rural India. Indian Journal of Medical Research. 2005 Sep 1; 122(3):258.

17. Vaz K, McGrowder D, Alexander-Lindo R, Gordon L, Brown P, Irving R. Knowledge, awareness and compliance with universal precautions among health care workers at the University Hospital of the West Indies, Jamaica. Int J Occup Environ Med (The IJOEM). 2010 Sep 21; 1 (4 October).
18. Ogoina D, Pondei K, Chima G, Isichei C, Gidado $S$. Knowledge, attitude and practice of standard precautions of infection control by hospital workers in two Tertiary Hospitals in Nigeria. J Infect Prev. 2015; 16:16-22.

19. Gershon RR, Vlahov D, Felknor SA, Vesley D, Johnson PC, Delcios GL, Murphy LR. Compliance with universal precautions among health care workers at three regional hospitals. American journal of infection control. 1995 Aug 1; 23(4):225-36.

20. Kotwal A, Taneja DK. Health care workers and universal precautions: Perceptions and determinants of noncompliance. Indian journal of community medicine: official publication of Indian Association of Preventive \& Social Medicine. 2010 Oct; 35(4):526.

21. Sadoh WE, Fawole AO, Sadoh AE, et al. Practice of universal precautions among healthcare workers. $J$ Natl Med Assoc 2006; 98(5):722-6.

22. Danchaivijitr S, Tantiwatanapaiboon Y, Chokloikaew S, et al. Universal precautions: Knowledge, compliance and attitudes of doctors and nurses in Thailand. $J$ Med Assoc Thai 1995; 78 Suppl 2:S112- S117.

23. Cutter J, Jordan S. Uptake of guidelines to avoid and report exposure to blood and body fluids. J Adv Nurs 2004; 46(4):441-52.

24. Wu S, Li L, Wu Z, Cao H, Lin C, Yan Z, et al. Universal precautions in the era of HIV/AIDS: Perception of health service providers in Yunnan, China. AIDS Behav. 2008; 12:806-14.

25. Iliyasu G, Dayyab FM, Habib ZG, Tiamiyu AB, Abubakar $S$, Mijinyawa MS, Habib AG. Knowledge and practices of infection control among healthcare workers in a Tertiary Referral Center in North-Western Nigeria. Annals of African medicine. 2016 Jan; 15(1):34.

\begin{tabular}{|c|c|c|c|}
\hline \multicolumn{4}{|c|}{ AUTHORSHIP AND CONTRIBUTION DECLARATION } \\
\hline Sr. \# & Author(s) Full Name & Contribution to the paper & Author(s) Signature \\
\hline 1 & Saleeem Raza Shah & Concept and synopsis. & \\
\hline 2 & Sajid Aziz & $\begin{array}{l}\text { Conceptual design and } \\
\text { review. }\end{array}$ & \\
\hline 3 & Ovais Ahmed Cheema & Data collection and analysis. & \\
\hline 4 & Salman Farooq Dar & Data analysis and article & \\
\hline 5 & & $\begin{array}{l}\text { Critical review and final } \\
\text { approval. }\end{array}$ & \\
\hline
\end{tabular}

